研 究

\title{
軟磁性フェロックスプラナ型フェライトの高周波磁気特性
}

\author{
松浦準山1,2, 河野 健二引2, 神島 謙二乡1, 柿崎 浩一心1, 平塚 信之心1 \\ ↔1 埼玉大学大学院理工学研究科, †338-8570さいたま市桜区下大久保 255 . \\ 山2 太陽誘電(侏)，广 370-3347 群馬県群馬郡榛名町中室田 5607-2.
}

\section{High Frequency Properties of Soft Magnetic Ferroxplana Type Ferrites}

\author{
Hitoshi Matsuura ${ }^{1,2}$, Kenji Kawano ${ }^{\text {if } 2}$, Kenji Kamishima ${ }^{\text {th } 1}$, Koichi Kakizaki ${ }^{\text {in } 1}$ and Nobuyuki Hiratsuka ${ }^{\text {is } 1}$ \\ ${ }_{4}^{2}$ Graduate School of Science and Engineering, Saitama University, 255 Shimo-ohkubo, Sakura-ku, Saitama 338-8570, Japan. \\ मे 2 Taiyo Yuden Co., Ltd, 5607-2 Nakamuroda, Haruna, Gunma 370-3347, Japan.
}

Received November 2, 2005

\section{SYNOPSIS}

Y-type $\left(\mathrm{Ba}_{2} \mathrm{Zn}_{2} \mathrm{Fe}_{12} \mathrm{O}_{22} ; \mathrm{Y}\right)$, M-type $\left(\mathrm{BaCo}_{1.1} \mathrm{Ti}_{1.1} \mathrm{Fe}_{9.8} \mathrm{O}_{19} ; \mathrm{M}_{\mathrm{CT}}\right)$ and mixture of these hexagonal ferrites $\left(\mathrm{Y}+\mathrm{xM} \mathrm{M}_{\mathrm{CT}}\right.$; $\mathrm{x}=0 \sim 3$ ) were prepared by the conventional solid-state reaction approach. Samples were made with $\mathrm{BaCO}_{3}, \mathrm{ZnO}$, $\mathrm{CoO}, \mathrm{TiO}_{2}$ and $\alpha-\mathrm{Fe}_{2} \mathrm{O}_{3}$ as starting materials. The frequency dependence of the initial permeability of all samples was measured using an impedance analyzer (HP4291B). The initial permeability of $\mathrm{Ba}_{3} \mathrm{Zn}_{2} \mathrm{Co}_{1.1} \mathrm{Ti}_{1.1} \mathrm{Fe}_{21.8} \mathrm{O}_{41}(\mathrm{x}=1)$ was 23 (at $100 \mathrm{MHz}$ ), which is the highest value in this study and the Snoek's product of this sample has been reached to $14.7 \mathrm{GHz}$. This value is twice larger than that of $\mathrm{Zn}_{2} \mathrm{Y}$. The detailed analysis of frequency dependent permeability curves for these samples strongly suggests that this enhancement of the Snoek's product is due to the change of magnetic anisotropy caused by the substitution of $\mathrm{Co}^{2+}$ and $\mathrm{Ti}^{4+}$ ions for $\mathrm{Fe}^{3+}$ ions.

KEY WORDS

hexagonal ferrite, permeability, anisotropy

\section{1 緒 言}

電子機器の小型化, 高性能化に伴い, 使用される周波数域 は $\mathrm{GHz}$ 帯へ移行し，この周波数帯で使用できる新規な磁性材 料の開発が要請されている.積層チップインダクタ(MLCI)に おいては, 従来から使用されている $\mathrm{Ni}-\mathrm{Cu}-\mathrm{Zn}$ フェライトよ りも高い初透磁率を超高周波帯域において維持できる材料が 要求される.

この新規磁性材料として有望なのが六方晶系フェライトの 中でも, $\mathrm{c}$ 面を磁化容易面に持つフェロクスプラナ型フェラ イトである.これはすべての $\mathrm{Y}$ 型フェライト $\left(\mathrm{Ba}_{2} \mathrm{Me}_{2} \mathrm{Fe}_{12} \mathrm{O}_{22}\right.$, $\mathrm{Me}=\mathrm{Mn}, \mathrm{Fe}, \mathrm{Co}, \mathrm{Cu}, \mathrm{Zn}, \mathrm{Mg}), 2$ 価イオンがCoである $\mathrm{Z}$ 型フェ ライト $\left(\mathrm{Ba}_{3} \mathrm{Co}_{2} \mathrm{Fe}_{24} \mathrm{O}_{41}\right)$ および $\mathrm{W}$ 型フェライト $\left(\mathrm{BaCo}_{2} \mathrm{Fe}_{16} \mathrm{O}_{27}\right)$ が知られている.これらのフェライトは, スピネル型フェラ イトに代わる高周波用軟磁性フェライトとして期待されてい るが, 初透磁率が小さいこと, 結晶構造が複雑なため単相を 得ることが難しいこと, および焼成温度が高いことが実用化 するにあたっての課題となっている ${ }^{1,2)}$.

一方, $\mathrm{M}$ 型フェライト $\left(\mathrm{MFe}_{12} \mathrm{O}_{19}, \mathrm{M}=\mathrm{Ba}, \mathrm{Sr}, \mathrm{Pb}\right)$ 法硬磁性 フェララトとして知られており, その高い飽和磁化值および
磁気異方性により永久磁石として使用されている.しかし， この $\mathrm{M}$ 型フェライトの $\mathrm{Fe}^{3+}$ イオンを $\mathrm{Co}^{2+}$ および $\mathrm{Ti}^{4+}$ イオンに より置換することにより, 磁気異方性および保磁力が減少す るとの報告がある ${ }^{3-7)}$.

そこで本論文では，Fig.1 に示すY型から M 型までを結ぶ 直線上の試料を作製するとともに, 六方晶型フェライトの $\mathrm{M}$ 型ブロックの $\mathrm{Fe}^{3+}$ イオンを $\mathrm{Co}^{2+}$ および $\mathrm{Ti}^{4+}$ イオンにより置換 し, 磁気異方性を変化させることによる初透磁率の向上を目 指し，それらの透磁率の周波数依存性を検討した。

\section{2 実験方法}

試料は通常の固相反応法を用いて作製した. 出発原料として 市販の $\mathrm{BaCO}_{3}, \mathrm{ZnO}, \mathrm{CoO}, \mathrm{TiO}_{2}$ および $\alpha-\mathrm{Fe}_{2} \mathrm{O}_{3}$ を用いて, $\mathrm{Co}-\mathrm{Ti}$ 置換 $\mathrm{M}$ 型フェライト $\left(\mathrm{BaCo}_{1.1} \mathrm{Ti}_{1.1} \mathrm{Fe}_{9.8} \mathrm{O}_{19}\right.$, 以下 $\mathrm{M}_{\mathrm{CT}}$ と称する $)$ および $\mathrm{Y}$ 型フェライト $\left(\mathrm{Ba}_{2} \mathrm{Zn}_{2} \mathrm{Fe}_{12} \mathrm{O}_{22}\right.$, 以下 $\mathrm{Y}$ と称する)の組 成となるように秤量した.これらの粉末をボールミルで 24 時 間混合した後, 成型し $1150^{\circ} \mathrm{C}$ で 2 時間大気中において仮焼成 した.これらの試料を $\mathrm{Y}+\mathrm{xM}_{\mathrm{CT}}(\mathrm{x}=0 \sim 3.0)$ の組成となるよ うに秤量した粉末および $\mathrm{M}_{\mathrm{Cr}}$ を遊星ボールミルで15分間粉砕 


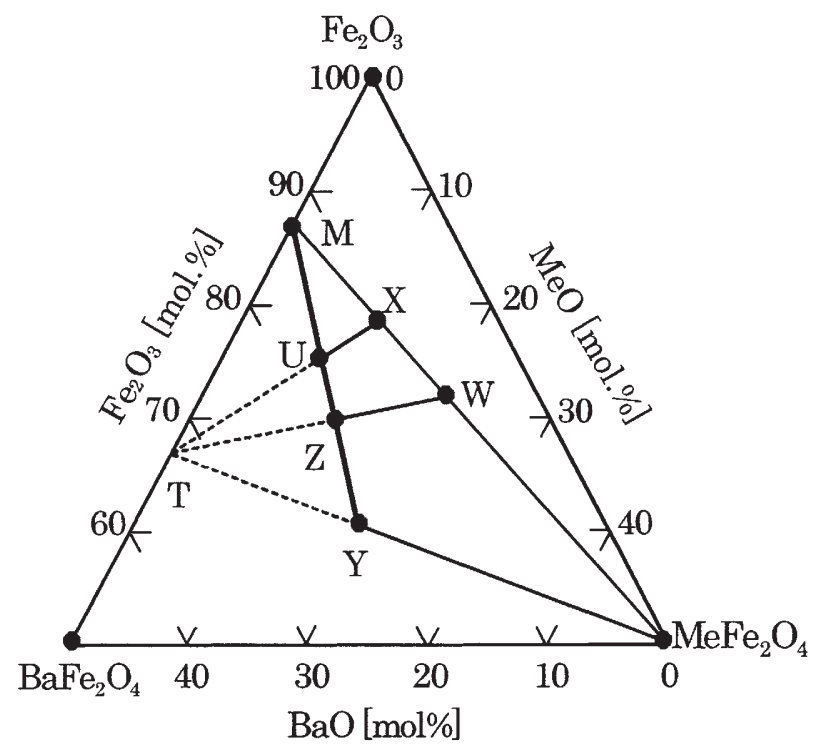

Fig.1 Composition diagram of hexagonal ferrites $(\mathrm{Me}=\mathrm{Mn}, \mathrm{Fe}$, $\mathrm{Co}, \mathrm{Cu}, \mathrm{Zn}, \mathrm{Mg}$ ).

した. 得られた粉末を $0.5 \mathrm{ton} / \mathrm{cm}^{2}$ でトロイダル状(外径 $9 \mathrm{~mm}^{\phi}$, 内径 $4.5 \mathrm{~mm}^{\phi}$, 厚さ $2.5 \mathrm{~mm}$ ) に成型した後, $1250^{\circ} \mathrm{C}$ で 5 時間, 大気中で焼成し, 炬内で放冷した.

得られた焼結体の初透磁率の周波数依存性は, ベクトルイ ンピーダンスアナライザ(HP4291B)で $1.0 \mathrm{M} \sim 1.8 \mathrm{GHz}$ の範囲 で測定した. 結晶構造の同定は，X線回折法で行った。焼結 体表面の微細構造は, 走查型電子顕微鏡 (SEM) により観察し た. 磁化值, 保磁力および見かけの異方性磁界は, 振動試料 型磁力計 (VSM) で測定した.

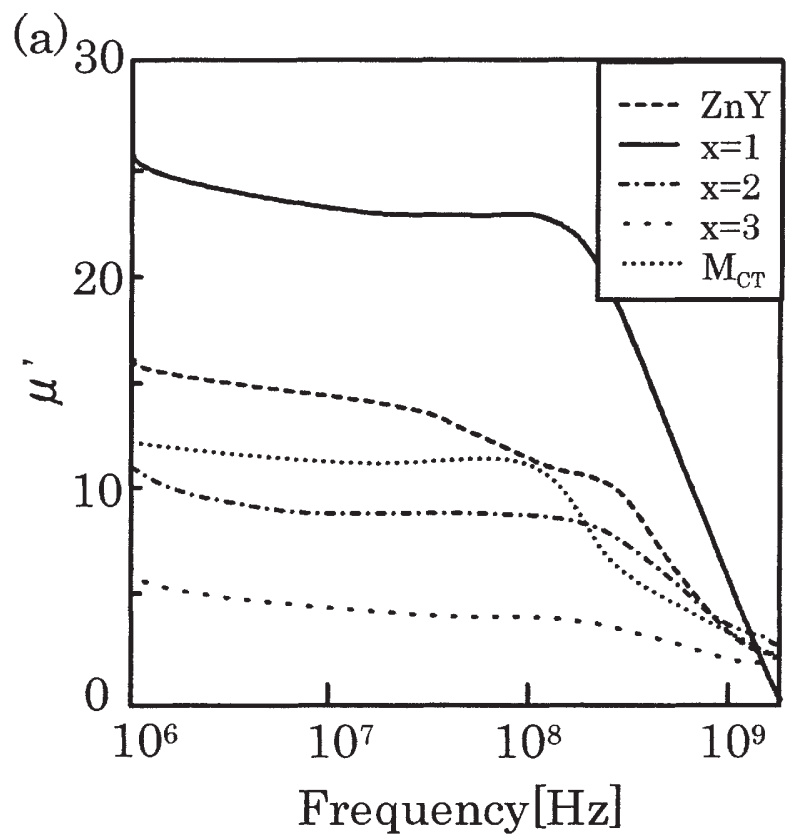

\section{3 結果および考察}

Fig. 2 は, $1250^{\circ} \mathrm{C}, 5$ 時間焼成した各試料の初透磁率の周波数 依存性を, また Fig.3は $10 \mathrm{MHz}$ における初透磁率の $\mathrm{x}\left(=\mathrm{M}_{\mathrm{Cr}} / \mathrm{Y}\right)$ 依存性を示す。初透磁率はY $\mathrm{Y}$ では $15, \mathrm{M}_{\mathrm{CT}}$ では 12 となった。 $\mathrm{x}=1$ の試料において初透磁率峙も大きく 23 となるが， $\mathrm{x}$ が 增加するとともに初透磁率は減少する. M型フェライトは本 来硬磁性であり, また $\mathrm{Ba}_{3} \mathrm{Zn}_{2} \mathrm{Fe}_{24} \mathrm{O}_{41}$ (以下 $\mathrm{Zn}_{2} \mathrm{Z}$ ) はc 面内に磁 気異方性を持たないため，それぞれ大きな透磁率を持たない

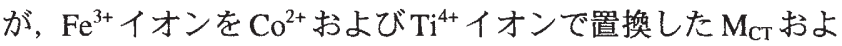
びZ型組成の $\mathrm{x}=1$ において初透磁率が増加した.このような

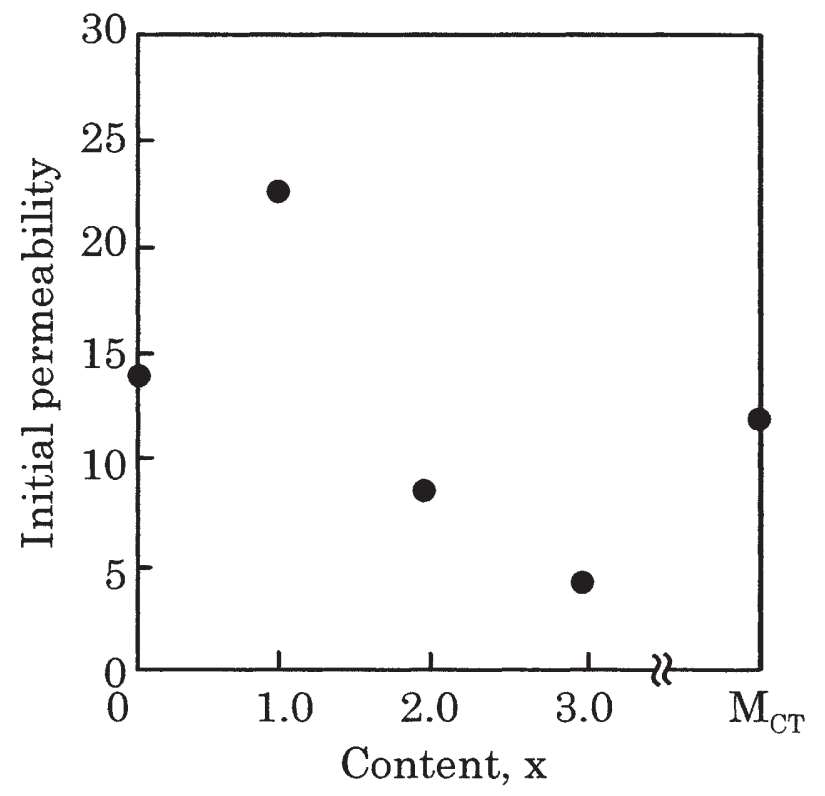

Fig.3 Dependence of initial permeability for $\mathrm{Y}+\mathrm{M}_{\mathrm{CT}}$ at $10 \mathrm{MHz}$.

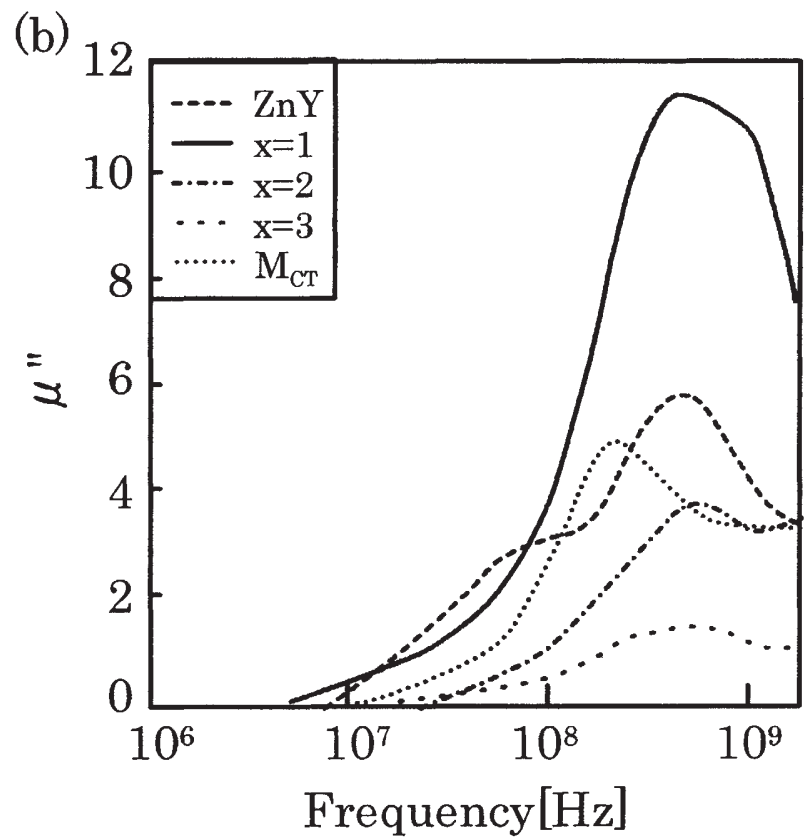

Fig.2 The complex permeability spectra (real par $\mathrm{t}(\mathrm{a})$ and imaginary part (b)) of $\mathrm{Y}+\mathrm{xM} \mathrm{M}_{\mathrm{CT}}$. 
結果となつた要因を結晶相, 磁気異方性および飽和磁化值よ り検討する.

Fig. 4 は $1250^{\circ} \mathrm{C}$ で 5 時間焼成した試料のX線回折図を示す. 作製した試料の内，代表的な試料として $\mathrm{x}=0,1.0$ および $\mathrm{Co}^{2+} \mathrm{Ti}^{4+}$ 置換 $\mathrm{M}$ 型フエライト $\mathrm{M}_{\mathrm{CT}}$ を示す. $\mathrm{x}=0$ および $\mathrm{M}_{\mathrm{CT}}$ の 試料ではそれぞれ，Y型およびM型フェライトの単相となっ ている. また, $\mathrm{x}=1.0$ の試料では目的とする $\mathrm{Z}$ 型が主相であ るが，若干の M型およびY型からの回折線が見られた。これ ら3つの試料以外ではすべて $\mathrm{Y}$ 型, M 型およびZ型の混相之 なっていた.これは, $\mathrm{x}=2$ でのU型フェライトでは $\mathrm{Z}$ 型フェ ライトと $\mathrm{M}$ 型フェライトの足し合わせという構造のため, 格 子定数が $\mathrm{a}$ 軸 $5.88 \AA \mathrm{c}$ 軸 $113.2 \AA$ と非常に異方的な構造となつ ていることにより, 生成に大きなエネルギーが必要なためと 考えられる.これらのことより, 単相が得られた $\mathrm{x}=0$ と $\mathrm{M}_{\mathrm{CI}}$ およびZ型フェライトが主相である $\mathrm{x}=1.0$ の試料において大 きな初透磁率が得られた。しかし，そのほかの中間組成梳六 方晶型ではあるが大きな初透磁率は得られなかった.

次に, 初透磁率について考察する. 初透磁率は以下の式の ように示される。

$$
\mu_{i} \propto \frac{M_{s}^{2}}{K}
$$

$\mathrm{M}_{\mathrm{s}}$ は飽和磁化値である。ここでの $\mathrm{K} は$, 結晶磁気異方性, 磁 気ひずみ, 内部応力などを含めた総括的な異方性定数である. 実際には $\mu_{\mathrm{i}}$ は磁壁移動や外部磁界, 反磁界の有無, 磁化回転, 焼結体の微細構造などにも影響を受けるため, 式1のように 単純には示せない.しかし, 式(1) は $\mu_{\mathrm{i}}$ の物理的な目安の概 念を得るには有効であることからVSMによるMsおよび異方 性磁界の测定を行った。

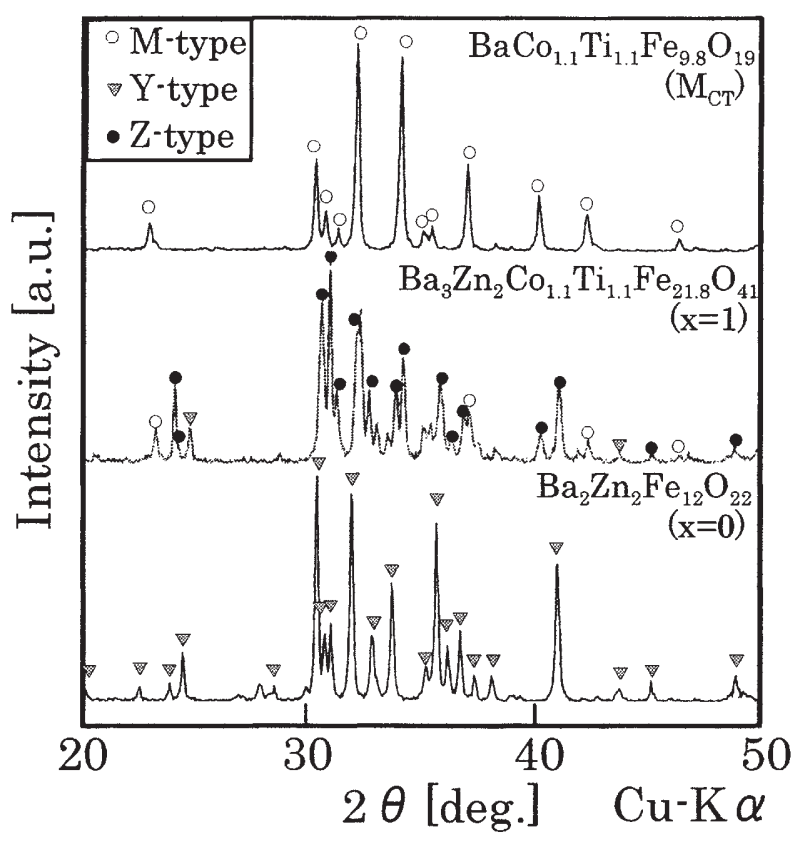

Fig.4 XRD patterns of hexagonal ferrites for $\mathrm{Y}+\mathrm{xM}_{\mathrm{CT}}$ sintered at $1250{ }^{\circ} \mathrm{C}$ for $5 \mathrm{~h}$ in air.
まず，磁気異方性による影響を異方性磁界より検討した。 多結晶体の異方性磁界を測定することはきわめて難しい. そ のため,ここではVSMによって测定した磁化曲線において磁 化が飽和する磁界を見かけの異方性磁界 $\left(\mathrm{H}_{\mathrm{A}}\right)$ と定義した. $\mathrm{Zn}_{2} \mathrm{Y}(\mathrm{x}=0)$ の異方性磁界は9.0 kOe と報告されており ${ }^{3)}$, 作製 した $\mathrm{x}=0$ での测定值は $9.2 \mathrm{kOe}$ であった. したがって,この 定義の信頼性が確認された。一般に $\mathrm{M}$ 型フエライトおよび $\mathrm{Zn}_{2} \mathrm{Z}$ は面内の異方性を持たないため, 大きな初透磁率を持た ず, $\mathrm{H}_{\mathrm{A}}$ は無置換 $\mathrm{M}$ 型フェライトでは $17 \mathrm{kOe}$, 無置換 $\mathrm{Zn}_{2} \mathrm{Z}$ では $13 \mathrm{kOe}$ であると報告されている3 ${ }^{3)}$. 作製した試料では $\mathrm{M}_{\mathrm{CT}}$ で $4.9 \mathrm{kOe}, \mathrm{Z}$ 型フェライトの組成である $\mathrm{x}=1.0$ の試料で $7.8 \mathrm{kOe}$ とかなり減少した.この理由として, $\mathrm{M}_{\mathrm{CT}}$ の組成においては, 置換により $\mathrm{Fe}^{3+}$ イオン間の磁気的結合が弱まるため, $\mathrm{c}$ 軸方 向の異方性磁界が 0 となり, 面内方向にわずかな異方性磁界 を持つことが報告されている ${ }^{5)}$. 今回作製した $\mathrm{M}_{\mathrm{CT}}$ において は，その異方性磁界の大きさより $\mathrm{c}$ 軸方向の異方性磁界が存 在すると推察されるが, Coの蒸発等による組成のずれが生じ ているためと考えられる.これはCoの蒸気圧が $\mathrm{Fe}, \mathrm{Ti}$ と比較 して高いことによると考えられるが，蛍光X線による組成分 析では，明確な組成のずれは確認できなかった。

また， $\mathrm{x}=1.0$ において異方性磁界が減少する理由として, $\mathrm{Co}^{2+} \mathrm{Ti}^{4+}$ 置換 $\mathrm{M}$ 型フェライト $\mathrm{M}_{\mathrm{CT}}$ をその構造中に含むことに より, $\mathrm{M}_{\mathrm{CT}}$ と同様の理由から $\mathrm{c}$ 軸方向の磁気異方性が減少し たと推察される.さらに, $\mathrm{x}=1$ では, 構造中の $\mathrm{Y}$ 型フェライ トからの面内磁気異方性が存在するため, 高周波においても 大きな初透磁率を示す．このことから，異方性磁界の低下が $\mathrm{M}_{\mathrm{CT}}$ および $\mathrm{x}=1$ において大きな初透磁率が得られた理由のひ とつであるといえる。

次に, 飽和磁化より考察を行う. Fig.5は各組成における飽 和磁化および保磁力を示す. $\mathrm{x}=0(\mathrm{Y})$ では報告されている磁 化值とほぼ同じ值が得られているが, $\mathrm{M}_{\mathrm{CT}}$ では無置換の $\mathrm{M}$ 型 フェライトと比較し, 磁化值が減少していた。これは, M型

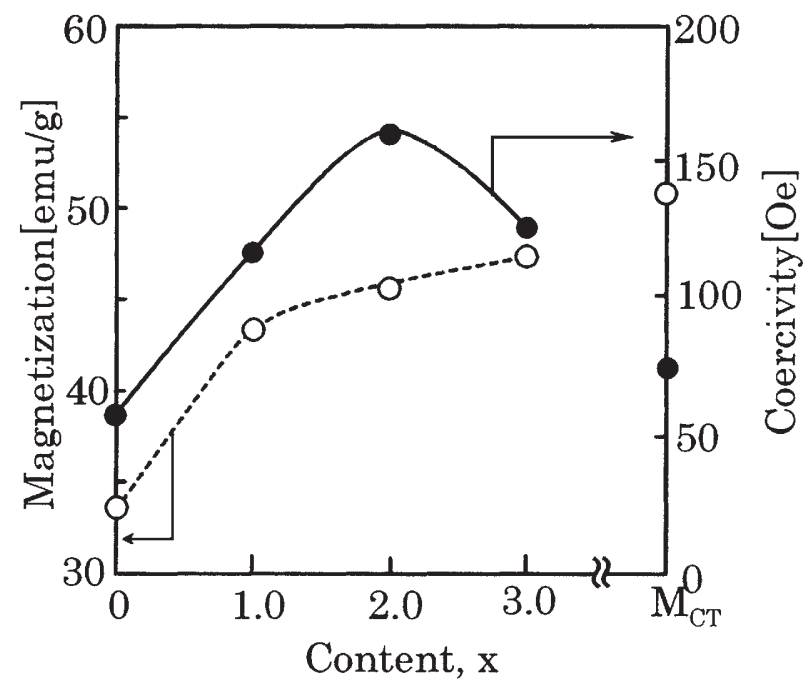

Fig.5 Saturation magnetization and coercivity for $\mathrm{Y}+\mathrm{xM}_{\mathrm{CT}}$. 


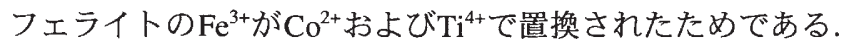
一方，これらの中間の組成 $(\mathrm{x}=1,2)$ において $\mathrm{x}=0$ および $\mathrm{M}_{\mathrm{CI}}$ よりも大きな磁化值となった。 これは，Y型フェライト内の $\mathrm{Zn}^{2+}$ イオンおよびM型フエライト内の $\mathrm{Co}^{2+}$ イオンが, 焼成時 に拡散し，M型フェライト部に $\mathrm{Zn}^{2+}$ イオンが固溶したためと 推察される. $\mathrm{x}=1.0$ および 2.0 において保磁力が大きくなって いることからもこの推祭を説明できる. したがって, $\mathrm{x}=1.0$ で大きな初透磁率が得られたのは, $\mathrm{Co}^{2+}$ および $\mathrm{Ti}^{4+}$ の置換に よる磁気異方性の低下および磁化值の増加によるものと考え られる。

VSMの結果からMsおよび磁気異方性が得られ，(1)式を用 いて各試料の初透磁率を定性的に議論できることをここまで に示した. しかしながら, 初透磁率の周波数特性には, Fig.2 に示すように $\mu$ 小よび $\mu$ ”が 2 段階で減少している試料がみ られた. Yangらにより報告されているY型フェライトにおい ても同様の挙動が見られる ${ }^{8}$ が, その原因については明確に はなつておらず,これらの透磁率の周波数特性について解析 する必要がある. 透磁率は磁壁移動と回転磁化成分に分けて, 以下の式から説明できることが一般に知られている ${ }^{9}$.

$$
\begin{aligned}
& \mu(w)=1+\chi_{s p i n}(w)+\chi_{d w}(w), \\
& \chi_{s p n n}(w)=\frac{K_{s}}{1+i\left(w / w_{s p p n}\right)}, \\
& \chi_{d w}(w)=\frac{K_{d w} w_{d w}^{2}}{w_{d w}^{2}-w^{2}+i \beta w},
\end{aligned}
$$

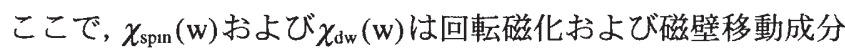
を示す. $\mathrm{K}_{\mathrm{s}}, \mathrm{K}_{\mathrm{dw}}$ は回転磁化および磁壁移動の静的磁化率であ る. $\mathrm{w}_{\mathrm{spin}}$ および $\mathrm{w}_{\mathrm{dw}}$ は回転磁化および磁壁移動による共鳴周 波数で, $\beta$ 核壁移動における減衰係数である.これらの式 を用いて実験結果をフィッティングにより解析し, 各パラ
メー夕の值を決定した. Fig.6に $\mathrm{x}=0$ (a) と $\mathrm{x}=1$ (b) の解析結 果を, 実験結果とともに示す。図が示すように, 解析結果は 実験結果を比較的よく記述していることが分かる．解析に よって得られた, 各パラメータの值は $\mathrm{x}=0$ の場合, $\mathrm{K}_{\mathrm{s}}=11.2$, $\mathrm{w}_{\mathrm{spnn}}=525 \mathrm{MHz}, \mathrm{K}_{\mathrm{dw}}=1.6, \mathrm{w}_{\mathrm{dw}}=78 \mathrm{MHz}, \beta=100 \mathrm{MHz}$ でおび $\mathrm{x}=1$ の場合, $\mathrm{K}_{\mathrm{s}}=20.0, \mathrm{w}_{\mathrm{spn}}=699 \mathrm{MHz}, \mathrm{K}_{\mathrm{dw}}=2.76, \mathrm{w}_{\mathrm{dw}}=355$ $\mathrm{MHz}, \beta=356 \mathrm{MHz}$ となった.

解析結果から，2つの試料ともに回転磁化による透磁率へ の寄与が大きく, 磁壁移動の影響が小さいこと, また, 雨者の 共鳴周波数が異なり, 特に $\mathrm{x}=0$ の場合には, 低周波側で共鳴 する磁壁の影響で透磁率の周波数特性が 2 段階になることが 示されている. $\mathrm{x}=1$ の場合, 磁壁の共鳴周波数が $\mathrm{x}=0$ より も高い. Fig.7に示すように, 2 つの試料で粒径が異なり, $x=1$ の方が粒径が小さい. 磁壁は粒界でもピンニングされること から, 粒径が小さいほど磁壁がピンニングされやすくなり, 透磁率は低下するが, 共鳴周波数自体は高周波化するものと 考えられる.いずれにしても, 解析結果が示すように, 測定 された值は回転磁化の寄与が大きいことから，作製した六方 晶フェライトの初透磁率は, 微細構造よりも組成による影響 が大さいといえる.

$\mathrm{x}=0$ の試料の Snoek 積は $6.4 \mathrm{GHz}$ となり, スピネル系フエ ライトの限界である $5.6 \mathrm{GHz}$ を超える值が得られている ${ }^{10}$. 一 方, $\mathrm{x}=1$ の試料の Snoek 積は $14.7 \mathrm{GHz}$ となり, $\mathrm{x}=0$ を 2 倍以 上上回る值が得られた.これは $\mathrm{Co}^{2+} \mathrm{Ti}^{4+}$ 置換によるc軸方向の 磁気異方性の減少に加え, M 型フェライトおよび Znイオン に由来する大きな磁化値によるものと考えられる.このこと より, 本来 $\mathrm{c}$ 面内に磁気異方性を持たないCo以外の 2 価のイ オンにより構成された Z 型フェライトにおいても, c 軸磁気 異方性を減少させることにより, 初透磁率の改善が可能なこ とが示された。

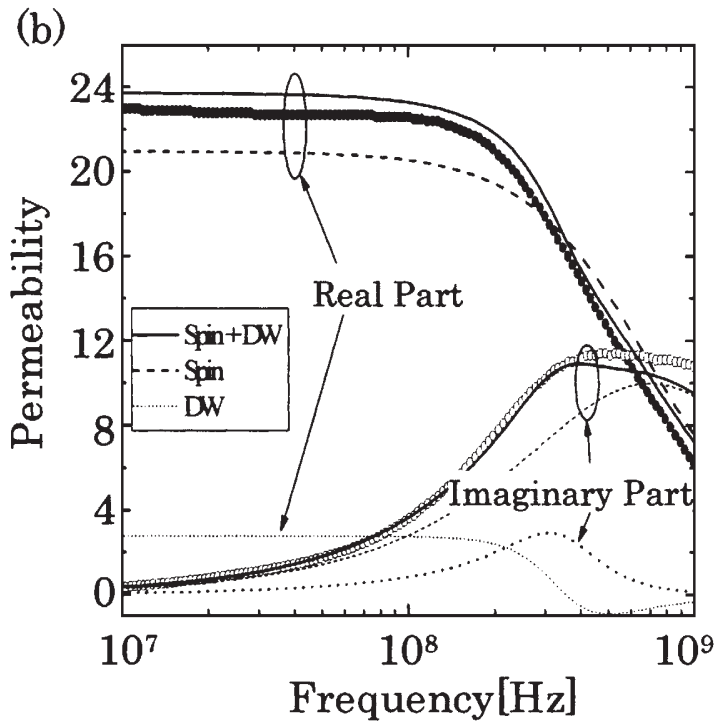

Fig.6 Complex permeability and simulated permeability spectra of $x=0(a)$ and $x=1(b)$. 

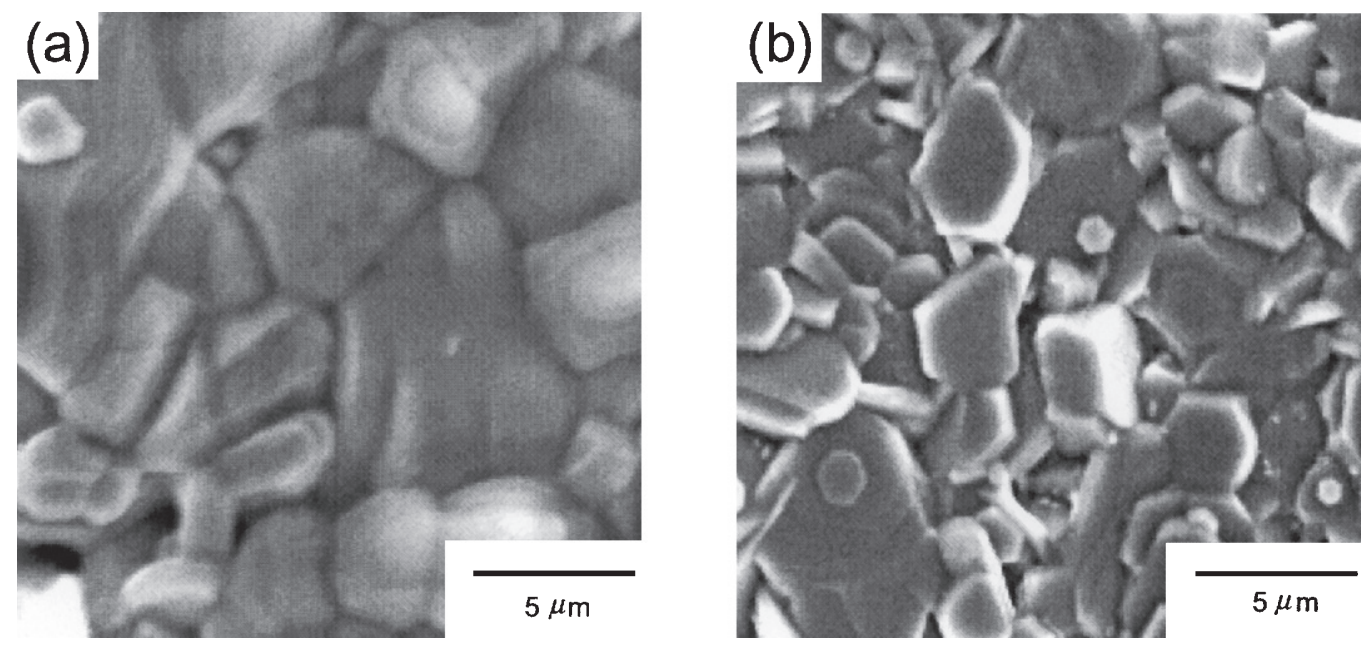

Fig.7 SEM images of $x=0(a)$ and $x=1(b)$.

\section{4 ま とめ}

$\mathrm{Y}$ 型フェライト, $\mathrm{Co}^{2+} \mathrm{Ti}^{4+}$ 置換 $\mathrm{M}$ 型フエライトおよびそれ らを足し合わせた組成の試料を作製し，以下の結果を得た。

(1) 本来硬磁性である M 型フェライトおよび面内に磁気異方 性を持たない $\mathrm{Zn}_{2} \mathrm{Z}$ において, $\mathrm{Fe}^{3+}$ を $\mathrm{Co}^{2+}$ および $\mathrm{Ti}^{4+}$ によ り置換することにより，12および23 と大きな初透磁率が 得られた。

(2) Z 型組成において大きな初透磁率が得られた原因は, $\mathrm{Co}^{2+} \mathrm{Ti}^{4+}$ 置換 $\mathrm{M}$ 型フェライトを含む六方晶では, 磁気異方 性が減少するためである.

（3）作製した Y 型および Z 型試料の透磁率は磁壁移動と比較 して，回転磁化の寄与が大きいと考えられる。したがっ て, 透磁率の変化には組成のコントロールが有効と考えら れる。

\section{文献}

1) H.Zhang, J.Zhou, Y.Wang, L.Li, Z.Yue and Z.Gui: "The effect of $\mathrm{Zn}$ ion substitution on electromagnetic properties of lowtemperature fired Z-type hexaferrite", Ceramics International, 28(2002)917-923.

2) X.Wang, L.Li, Z. Yue, S.Su, Z.Gui and J.Zhou: "Preparation and magnetic characterization of the ferroxplana ferrites $\mathrm{Ba}_{3} \mathrm{CO}_{2}$
${ }_{x} \mathrm{Zn}_{\mathrm{x}} \mathrm{Fe}_{24} \mathrm{O}_{41}$ ", JMMM, 246(2002)434-439.

3) J.Smit and H.P.J.Wijn: "Ferrites", Philips Technical Library, (1959) 177-211.

4) H.Kojima: "Ferromagnetic materials", ed. E.P.Wolfarth, NorthHolland Pub., 3(1982) 305.

5) J.Kreisel, H.Vincent, F.Tasset, M.Pate and J.P.Ganne: "An investigation of the magnetic anisotropy change in $\mathrm{BaFe}_{12-2 \mathrm{x}}$ $\mathrm{Ti}_{\mathrm{x}} \mathrm{Co}_{\mathrm{x}} \mathrm{O}_{19}$ single crystals", JMMM, 224(2001)17-29.

6) K.Kakizaki and N.Hiratsuka: "Magnetic Properties of Crystal Structures of Acicular Barium Ferrite Particles", J. Magn. Soc. Japan, 22(1998) 129-131.

7) K.Kakizaki, N.Hiratsuka and T.Namikawa: "Fine Structure of Acicular $\mathrm{BaCo}_{x} \mathrm{Ti}_{\mathrm{x}} \mathrm{Fe}_{12-2 \mathrm{x}} \mathrm{O}_{19}$ Particles and Their Magnetic Properties", JMMM, 176(1997)36-40.

8) Y.Bai, J.Zhou, Z.Gui and L.Li: "Frequency dispersion of complex permeability of Y-type hexagonal ferrites", Materials Letters, 58(2004) 1602-1606.

9) T.Tsutaoka: "Frequency dispersion of complex permeability in $\mathrm{Mn}-\mathrm{Zn}$ and $\mathrm{Ni}-\mathrm{Zn}$ spinel ferrites and their composite materials", J. Appl. Phys., 93(2003)2789-2796.

10) J.L.Snoek: "Dispersion and absorption in magnetic ferrites at frequencies above one Mc/s", Physica, 14(1948)207-217. 